\title{
Formulations with green clay for acne-prone skin: evaluation of rheology and sensory
}

\author{
Formulações com argila verde para pele acneica: avaliação da reologia e do sensorial
}

\author{
Maria Cibelle Pauli Lungatto ${ }^{1}$, Silas Arandas Monteiro e Silva ${ }^{1}$, Andréa Cristina de Lima ${ }^{2}$, Anna Cecilia \\ Venturini $^{3}$, Vânia R. Leite e Silva ${ }^{3}$, Gislaine Ricci Leonardi ${ }^{1,3}$ \\ ${ }^{1}$ Medicine Department - Universidade Federal de São paulo - UNIFESP/ São Paulo - SP \\ ${ }^{2}$ Universidade Metodista de Piracicaba (UNIMEP) \\ ${ }^{3}$ Instituto de Ciências Ambientais, Químicas e Farmacêuticas - Universidade Federal de São Paulo - UNIFESP, Diadema-SP \\ Email: cibellepauli@hotmail.com
}

\begin{abstract}
Acne is an inflammatory skin condition that develops in pilosebaceous follicles, affecting mainly the onset of puberty. Among the numerous chemicals with dermatological and cosmetic purpose, traded and prescribed, raw materials of mineral origin have been often sought in formulations aimed at treating and / or preventing acne. This work aimed at the development of cosmetic preparations including green clay and sensory analysis of the formulations. Four formulations containing $2.5 \%$ to $5 \%$ green clay, in the presence or absence of dimethicone were prepared. The rheological behavior of the samples was analyzed at time 0,24 hours, 30 days, 60 days and 90 days, using a cone and plate type rheometer (DVII + viscometer, Brookfiel). Sensory analyses of the formulations were also made. It can be concluded that all formulations exhibited pseudoplastic behavior and, through statistical analysis, it was found that there were no significant differences in acceptance between the formulations with or without dimethicone in the attributes of spreadability, stickiness, color and sensation after application. However, in regard to the attribute of odor, it was found that there was a greater acceptance in formulations to which dimethicone was added.
\end{abstract}

Key words: Cosmetics; Green clay; Analysis Evaluation.

\begin{abstract}
Resumo
A acne é uma dermatose inflamatória que se desenvolve nos folículos polissebáceos, acometendo principalmente o início da puberdade. Entre os inúmeros ativos com finalidades dermatológicas e cosméticas, comercializados e prescritos, as matérias-primas de origem mineral vêm sendo muito almejadas nas formulações que visam tratar e/ou prevenir a acne. Esse trabalho teve como objetivo o desenvolvimento de preparações cosméticas acrescidas de Argila Verde e análise sensorial das formulações. Foram preparadas quatro formulações contendo a Argila Verde a $2,5 \%$ e a $5 \%$, com a presença ou não de dimeticone. Amostras foram analisadas no tempo 0,24 horas, 30 dias, 60 dias e 90 dias quanto ao seu comportamento reológico, utilizando reômetro tipo Cone \& Placa (DVII + VISCOMETER - Brookfiel). Efetuou-se também a análise sensorial das formulações. Pode-se concluir que todas as formulações apresentaram comportamento pseudoplástico, e através da análise estatística verificou-se que não houve diferenças significativas da aceitação entre as formulações com ou sem dimeticone nos atributos: espalhabilidade, pegajosidade, cor e sensação após aplicação. No entanto, para o atributo odor, verificou-se que houve uma maior aceitação nas formulações acrescidas de dimeticone.
\end{abstract}

Palavras-Chave: Cosméticos; Argila Verde; Análise Sensorial. 


\section{Introduction}

Acne is an inflammatory skin condition that develops in the sebaceous follicles, usually beginning at puberty. It is easily diagnosed, not thus seriously jeopardizing the health of the individual, however it can compromise the well-being of the patient, specifically their emotional development, causing in turn a decrease in self-esteem and behavioral modifications ${ }^{1}$.

Clay is a substance that has been used by mankind for many years, back to ancient civilizations. The Egyptians and Greeks used the application of clay in order to clean $\operatorname{skin}^{2-3}$. Currently face masks formed of clay have been used by dermatologists as a treatment because of its capacity of promoting beneficial skin effects, as the lifting action and dry skin ${ }^{4}$.

Hydrophilic gels have also been widely used in cosmetic and dermatological products, since they have good spreadability without being greasy. Therefore, some topical products for oily skin use hydrophilic gels as a cosmetic base ${ }^{5}$. Although most of the physicochemical properties of clay dispersion have already been studied, the specific aspects of stability and sensory evaluation of these properties are little known ${ }^{4}$.

Sensory evaluation is used to measure, analyze and interpret the characteristics of products according to the perception of the four senses (sight, smell, taste and touch). Although initially this analysis was used for food and beverages, sensory evaluation is widely applicable in pharmaceuticals, cosmetics and toiletries, such as toothpaste, shampoo, etc ${ }^{5-9}$.

The sensory evaluation of a cosmetic product is of paramount importance, as it affects the acceptance of the product by the consumer and consequently its potential for trade ${ }^{6}$. Therefore the sensory evaluation is vital to the success of a cosmetic product.

This work aimed to develop cosmetic preparations plus green clay and evaluate the rheological behavior and sensory acceptance of the formulations.

\section{Material and Methods}

Four different formulations of green clay (Table 1) were developed.

\section{Introdução}

A acne é uma dermatose inflamatória que se desenvolve nos folículos sebáceos, e geralmente tem início na puberdade, é de fácil diagnóstico, não comprometendo assim gravemente a saúde do indivíduo, mas por outro lado pode comprometer o bem-estar do paciente, o seu desenvolvimento emocional, ocasionando por sua vez uma diminuição da auto-estima e modificações comportamentais ${ }^{1}$.

A argila é uma substância que vem sendo utilizada pela humanidade por muitos anos. A utilização da mesma se reporta desde as antigas civilizações. Os egípcios e os gregos já utilizavam a aplicação da argila com o intuito de limpeza de pele ${ }^{2-3}$.

Atualmente a utilização de máscaras faciais constituídas de argila, tem sido empregada como tratamento pelos dermatologistas, devido a sua capacidade de promover efeitos benéficos a pele, como ação tensora e secativa da pele ${ }^{4}$.

Os géis hidrofílicos também vêm sendo amplamente utilizados em produtos cosméticos e dermatológicos, pois apresentam boa espalhabilidade, além de não serem gordurosos. Portanto, alguns produtos de uso tópico destinados a pele oleosa têm empregado como base cosmética os géis hidrofílicos ${ }^{5}$. Embora a maioria das propriedades físico-químicas de dispersão de argilas já tenham sido estudadas, os aspectos específicos quanto a estabilidade e a avaliação sensorial destas propriedades continuam pouco conhecidas ${ }^{4}$.

A avaliação sensorial é utilizada para medir, analisar e interpretar as características de produtos de acordo com a percepção dos quatro sentidos (visão, olfato, paladar e tato). Embora inicialmente esta análise seja utilizada para alimentos e bebidas, a avaliação sensorial é amplamente aplicável em produtos farmacêuticos, cosméticos e produtos de higiene pessoal tal como creme dental, shampoo, entre outros ${ }^{5-6-7-8-9}$.

O sensorial de um produto cosmético é um fator de suma importância, que interfere na aceitação do produto pelo consumidor e consequentemente, no seu potencial de venda ${ }^{6}$. Sendo assim a avaliação sensorial é de suma importância para o sucesso de um produto cosmético. O presente trabalho visou desenvolver preparações cosméticas acrescidas de Argila verde, e avaliar o comportamento reológico e a aceitação sensorial das formulações.

\section{Material e Métodos}

Foram desenvolvidas quatro diferentes formulações constituídas de Argila Verde (Tabela 1). 
All samples were prepared in triplicate, stored at ambient temperature at $(25 \pm 2)^{\circ} \mathrm{C}$, and analyzed for their rheological behavior and sensory acceptance.
Todas as amostras foram preparadas em triplicata, armazenadas em temperatura ambiente, a $(25 \pm 2){ }^{\circ} \mathrm{C}$, foram analisadas quanto ao seu comportamento reológico e aceitação sensorial.

Table 1 / Tabela 1 - Pharmaceutical formulations used in the study Fórmulas Farmacêuticas utilizadas no estudo.

\begin{tabular}{ccccc}
\hline $\begin{array}{c}\text { Components } \\
(\% \mathbf{\%} / \mathbf{P})\end{array}$ & F1 & F2 & F3 & F4 \\
\hline Carbomer & 0,5 & 0,5 & 0,5 & 0,5 \\
Propylene Glycol & 10 & 10 & 10 & 10 \\
Phenoxyethanol & 0,5 & 0,5 & 0,5 & 0,5 \\
Green Clay & 2,5 & 5 & 2,5 & 5 \\
Dimethicone & - & - & 5 & 5 \\
$\begin{array}{c}\text { Polyacrylamide, } \\
\text { isoparaffin and } \\
\text { laureth-7 }\end{array}$ & 4 & 4 & 4 & 4 \\
Triethanolamine & qs & Qs & qs & qs \\
Distilled water & qs & Qs & qs & qs \\
\hline
\end{tabular}

Analysis of the rheological behavior of the formulations

The formulations were analyzed in triplicate as to its rheological behavior at times 0 and 24 hours, 30 days, 60 days and 90 days, at room temperature, using a cone and plate type rheometer (DVII + Viscometer, Brookfiel), operating the Wingather V2.5 software.

\section{Sensory Evaluation of Formulations}

The study was approved by the ethics committee of the Methodist University of Piracicaba, No. 20/12.

Acceptance testing was performed with four cosmetic formulations for the attributes spreadability, stickiness, color, smell and feel after application. A 5-point hedonic scale was used for evaluation of the attributes of spreadability, color, smell and sensation after application $(1=$ poor; 2 = poor, 3 = fair, $4=$ good; 5 = excellent). To evaluate the tackiness of the samples, an intensity scale of 5 points ( 1 = very sticky; 2 = sticky; 3 = fairly sticky; $4=$ slightly sticky, $5=$ not sticky) was used. The evaluation of the samples was performed by a team consisting of 33 untrained consumers of cosmetic preparations of all ethnic groups, aged between 18 years to 50 years.
Análise do comportamento reológico das Formulações

As formulações foram analisadas, em triplicata, quanto ao seu comportamento reológico nos tempos 0 e 24 horas, 30 dias, 60 dias e 90 dias, na temperatura ambiente, utilizando o reômetro tipo Cone \& Placa (DVII + VISCOMETER - Brookfiel), operando o software Wingather V2.5.

\section{Avaliação Sensorial das Formulações}

O trabalho foi aprovado pelo comitê de ética da Universidade Metodista de Piracicaba, no 20/12.

$\mathrm{O}$ teste de aceitação foi realizado com as quatro formulações cosméticas, em relação aos atributos espalhabilidade, pegajosidade cor, odor e sensação após aplicação. Foi utilizada escala hedônica de 5 pontos para avaliação dos atributos espalhabilidade, cor, odor e sensação após aplicação (1=péssimo; 2 = ruim; $3=$ razoável; 4=bom; $5=$ excelente). Para avaliar a pegajosidade das amostras foi utilizada uma escala de intensidade de 5 pontos ( $1=$ muito pegajoso; $2=$ pegajoso; $3=$ razoavelmente pegajoso; 4=pouco pegajoso; 5=não pegajoso). A avaliação das amostras foi realizada por uma equipe composta de 33 provadores não treinados, 
The consumers were informed about the objectives and methods of the study and signed consent. The samples were presented to panelists in balanced complete block design in white cups coded with three-digit numbers. The volunteers applied a standardized amount of each formulation in different regions of the forearm and then were given a sheet of Sensory Evaluation, noting quality attributes. Results were analyzed by ANOVA and Tukey's test, using the Statistica software package (Statsoft Inc., Tulsa, OK, USA) The significance level used for all statistical analyzes was $5 \%(P<0.05)$.

\section{Results}

The mean values of the rheological parameters described as the consistency index are shown in Table 2. Under these time and storage conditions, it may be noted that the formulations plus dimethicone showed lower consistency index, i.e. lower viscosity. Conversely, polyacrylamide acts as a thickener in the formulation. The type of polymers used in a particular formulation may influence the rheological behavior and viscosity of the final product ${ }^{10}$. de todos os grupos étnicos e com faixa etária entre 18 anos e 50 anos, consumidores de preparações cosméticas, que foram orientados quanto aos objetivos e métodos da pesquisa e assinaram o termo de consentimento. Os voluntários aplicaram uma quantidade padronizada de cada formulação em regiões distintas do antebraço e em seguida receberam um Ficha de Avaliação Sensorial, onde atribuíram notas aos atributos de qualidade.

As amostras foram apresentadas aos provadores em delineamento de blocos completos balanceados, em copos brancos codificados com algarismos de três dígitos. Os resultados foram analisados por ANOVA e Teste de Médias de Tukey, utilizando-se o programa Statistica ${ }^{\mathrm{TM}}$ (Statsoft Inc., Tulsa, OK, USA) O nível de significância usado para todas as análises estatísticas foi $5 \%$ $(p<0,05)$.

\section{Resultados}

Os valores médios do parâmetro reológico descrito como índice de consistência (Tabela 2), em termos comparacionais relativos ao tempo e condição de armazenamento, mostram que as formulações acrescidas de dimeticone apresentaram menor valor de índice de consistência, ou seja menor viscosidade. A poliacrilamida age como espessante na formulação. O tipo de polímero empregado em determinada formulação pode influenciar o comportamento reológico e na viscosidade do produto final ${ }^{10}$.

Table 2 / Tabela 2. Mean values of the consistency index of the preparations involved in the study at room temperature at different time points

Média dos valores referentes ao índice de consistência das preparações envolvidas no estudo, acondicionado em temperatura ambiente, nos diferentes tempos estudados.

\begin{tabular}{|c|c|c|c|c|}
\hline $\begin{array}{c}\text { Time of } \\
\text { Analysis } \\
\text { Tempos de } \\
\text { Análises }\end{array}$ & \multicolumn{4}{|c|}{ MEAN / MÉDIA (n=3) } \\
& $\mathbf{F 1}$ & $\mathbf{F 2}$ & $\mathbf{F 3}$ & $\mathbf{F 4}$ \\
\cline { 2 - 5 } & $106603.33 \pm 3503$ & $1041945 \pm 5106$ & $98215.5 \pm 4213$ & $96964.5 \pm 4123$ \\
\hline $\boldsymbol{t}=\mathbf{0}$ & $103003.4 \pm 2657$ & $107184-33 \pm 5420$ & $96209.66 \pm 4782$ & $96119.66 \pm 3921$ \\
$\boldsymbol{t}=\mathbf{2 4} \mathbf{h}$ & $103449.3 \pm 1563$ & $103290-53 \pm 4250$ & $95186.53 \pm 1549$ & $89263.66 \pm 3245$ \\
$\boldsymbol{t}=\mathbf{3 0} \mathbf{d}$ & $108360.66 \pm 1783$ & $103209-933 \pm 3576$ & $95146-32 \pm 989$ & $95454.33 \pm 1478$ \\
$\boldsymbol{t}=\mathbf{6 0} \mathbf{d}$ & $105413.09 \pm 2713$ & $105265-33 \pm 5004$ & $95131-55 \pm 1732$ & $94452.33 \pm 987$ \\
$\boldsymbol{t}=\mathbf{9 0} \mathbf{d}$ & & & & \\
\hline \hline
\end{tabular}


Table 3/ Tabela 3. Mean values of the flow rate of the preparations involved in the study at room temperature at different time points

Média dos valores referentes ao índice de fluxo das preparações envolvidas no estudo, acondicionado em temperatura ambiente, nos diferentes tempos estudados.

\begin{tabular}{|c|c|c|c|c|}
\hline $\begin{array}{c}\text { Time of } \\
\text { Analysis } \\
\text { Tempos de } \\
\text { Análises }\end{array}$ & \multicolumn{5}{|c|}{ MEAN / MÉDIA (n=3) } \\
\cline { 2 - 5 } & $\mathbf{F 1}$ & $\mathbf{F 2}$ & $\mathbf{F 3}$ & $\mathbf{F 4}$ \\
\hline $\boldsymbol{t}=\mathbf{0}$ & $0.23 \pm 0.01$ & $0.21 \pm 0.02$ & $0,24 \pm 0.01$ & $0.23 \pm 0.01$ \\
$\boldsymbol{t}=\mathbf{2 4} \mathbf{h}$ & $0.22 \pm 0.01$ & $0.24 \pm 0.01$ & $0,23 \pm 0.02$ & $0.22 \pm 0.01$ \\
$\boldsymbol{t}=\mathbf{3 0} \mathrm{d}$ & $0.20 \pm 0.02$ & $0.23 \pm 0.02$ & $0,22 \pm 0.01$ & $0.20 \pm 0.01$ \\
$\boldsymbol{t}=\mathbf{6 0} \mathrm{d}$ & $0.18 \pm 0.02$ & $0.21 \pm 0.01$ & $0,20 \pm 0.01$ & $0.19 \pm 0.01$ \\
$\boldsymbol{t}=\mathbf{9 0} \mathbf{d}$ & $0.17 \pm 0.01$ & $0.18 \pm 0.01$ & $0,19 \pm 0.02$ & $0.18 \pm 0.02$ \\
\hline \hline
\end{tabular}

The mean values for the flow rates of the samples analyzed at different times and at room temperature, shown in Table 3, indicate that all the formulations showed pseudoplastic behavior (where $n<1$ ). In the rheograms shown in Figure 1, it can be seen that all samples showed a decrease in viscosity with increasing shear rate over time. The presence of hysteresis area (areas formed between the ascending and descending curves of each rheogram) indicates a thixotropic nature of the formulations.

Thus, the formulations studied showed desirable rheological behavior of cosmetic products, as by the application of force / pressure through the hands they must become more fluid, allowing good spreadability in the region where they are applied, and the viscosity should be recovered over time after ending the application of pressure by the hand. This prevents the drain of cosmetic product after application on the surface of the body.

Regarding the sensory aspect of the formulations, shown in table 4, it can be seen that the F3 and F4 formulations showed the highest odor acceptability among the tested formulations, indicating that the green clay associated with the presence of dimethicone had a positive influence on the acceptance of the formulation. The attributes of spreadability, stickiness, color and feel upon application were similar for all formulations tested, showing that these parameters were unaffected by the concentration of green clay or presence of dimethicone.
Os valores médios referentes aos índices de fluxo das amostras analisadas em diferentes tempos e na temperatura ambiente, nos quais estão representados na Tabela 3 , indicam que todas as formulações apresentaram comportamento pseudoplástico (onde $\mathrm{n}<1$ ). Ainda através dos reogramas apresentados na Figura 1, é possível observar que todas amostras apresentaram diminuição de sua viscosidade com o aumento da taxa de cisalhamento ao longo do tempo. A presença de área de histerese (áreas formadas entre as curvas ascendentes e descendentes de cada reograma) indica caracteristica tixotrópica das formulações.

Assim, as formulações estudadas mostraram comportamento reológico desejável aos produtos cosméticos, pois mediante a aplicação de força/pressão pelas mãos devem tornar-se mais fluidas, o que permitirá boa espalhabilidade na região onde serão aplicadas, e deverão ter a viscosidade recuperada, ao longo do tempo, no momento em que se encerra a aplicação da pressão pelas mãos, o que impede que o produto escorra após o procedimento de aplicação do produto cosmético sobre a superfície do corpo.

Quanto ao aspecto sensorial das formulações, representados na tabela 4, pode-se verificar que as formulações F3 e F4 foram as que apresentaram maior aceitabilidade de odor entre as formulações testadas, indicando que a argila verde associado à presença de dimeticonte interferiu positivamente na aceitação da formulação. Já os atributos espalhabilidade, pegajosidade, cor e sensação após aplicação foram similares para todas as formulações testadas, mostrando que esses atributos não foram afetados pela concentração de argila verde ou presença do dimeticone. 
A)

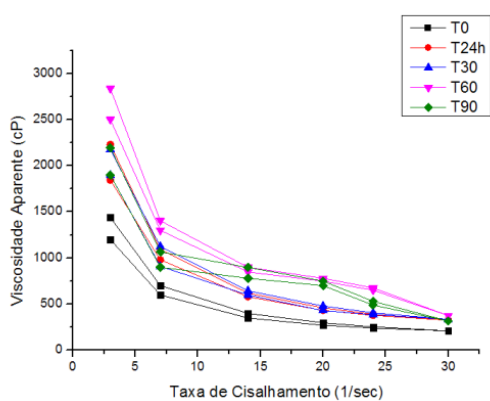

C)

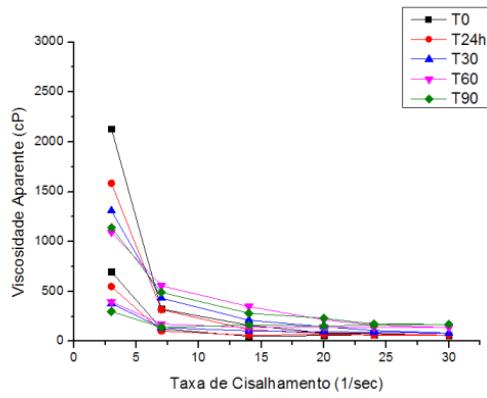

B)

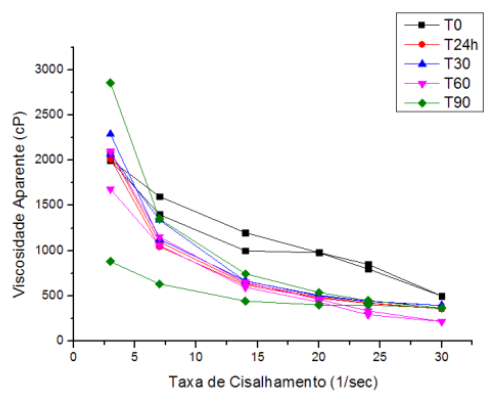

D)

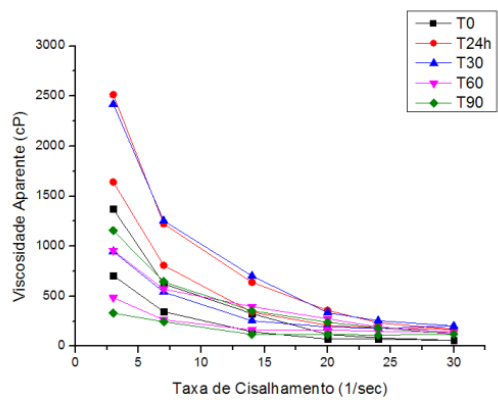

Figure 1 / Figura 1. Rheograms over time of the formulations studied, over time of analysis, where A (Formulation 1), B (formulation 2), C (Formulation 3) and D (Formulation 4)

Representação dos reogramas das formulações objeto de estudo, ao longo do tempo de análise, sendo A (Formulação 1), B (Formulação 2), C (Formulação 3) e D (Formulação 4).

Table 4 / Tabela 4 - Mean values and standard deviations of sensory notes $(n=33)$

Valores médios e desvio padrão das notas sensoriais $(\mathrm{n}=33)$.

\begin{tabular}{|c|c|c|c|c|c|}
\hline & Spreadability $^{1}$ & Tack $^{2}$ & Color $^{1}$ & Smell $^{1}$ & Feel $^{1}$ \\
\hline & Espalhabilidade $^{1}$ & Pegajosidade $^{2}$ & Cor $^{1}$ & Odor $^{1}$ & Sensação após ${ }^{1}$ \\
\hline $\mathrm{F} 1$ & $4.2 \pm 0.9^{a}$ & $4.6 \pm 0.7^{a}$ & $4.2 \pm 0.9^{a}$ & $3.8 \pm 0.9^{a}$ & $3.9 \pm 1.0^{a}$ \\
\hline $\mathrm{F} 2$ & $4.3 \pm 0.8^{a}$ & $4.6 \pm 0.7^{a}$ & $4.3 \pm 0.8^{a}$ & $3.6 \pm 0.9^{a}$ & $4.2 \pm 1.0^{a}$ \\
\hline & $\begin{array}{l}4.1 \pm 0.9 \text { a } \\
\text { fferent letters in the }\end{array}$ & $\begin{array}{l}4.6 \pm 0.6 \\
\text { ne column indicat }\end{array}$ & $\begin{array}{l}4.1 \pm 0.9 \\
\text { gnificant differen }\end{array}$ & $\begin{array}{l}3.9 \pm 0.8 \quad \mathrm{ab} \\
0.05) .\end{array}$ & $4.2 \pm 0.8^{a}$ \\
\hline \multicolumn{6}{|c|}{$\begin{array}{l}{ }^{1} \text { Spreadability, color, smell and feel after application: } 1=\text { poor; } 2=\text { poor; } 3=\text { fair; } \\
{ }^{2} \text { Tack: } 1=\text { very sticky; } 2=\text { sticky; } 3=\text { fairly sticky; } 4=\text { slightly sticky; } 5=\text { not stic } \\
{ }^{\text {ab }} \text { : Letra diferentes na mesma coluna indica diferença significativa }(P<0,05) \text {. }\end{array}$} \\
\hline
\end{tabular}




\section{Discussion}

When dealing with development of cosmetic products, it is extremely important to take into consideration the various tests to be performed as recommended by the health body of national competence ${ }^{11}$.

The evaluation criteria described as flow rate and consistency index match variables inherent to the cosmetic product, and whose determination is thus considered essential to configure the physical stability of cosmetics ${ }^{12}$. In dermocosmetic formulations widely used as carriers of active substances, the pseudoplastic flow is sought, since such formulations have their apparent viscosity gradually decreased with increasing shear voltage ${ }^{13}$, which facilitates the application of products on the skin. It is known that in the development of gels, it is extremely important to study the rheological characteristics when considering their manufacturing processes, transportation, storage and use by consumers. In this aspect, the rheological properties of the study considers a number of cosmetic formulations such as texture, consistency, spreadability. These characteristics have important factors in determining buying choices for various types of users ${ }^{14}$.

The mean values for the flow rates of the samples analyzed at different times and at room temperature, in which are shown in Table 3, indicated that all the formulations exhibited pseudoplastic behavior (where $n$ $<1$ ). According to the scientific literature regarding formulations for topical use, the pseudoplastic behavior is considered appropriate because after shearing (applying a force of spreadability), initial resistance to the product flow decreases, thus enabling better application and spreadability, and the reducing the intensity of shear force again increases resistance to the flow progressively ${ }^{15}$.

The analysis of the four formulations analyzed at different times and at room temperature, through the rheograms shown in Figure 1 indicates that all formulations show pseudoplastic and thixotropic behavior, with a decrease in viscosity with increasing the over time. These formulations become more fluid by applying more force, which may facilitate the spreadability of the product when applied to the skin.

The rheological properties of cosmetics are closely related to its filling and removal of the packaging material, and with the spreadability and adhesion of these on the skin. Thus, the study of these characteristics (viscosity, pour point, spreadability) can be used as a means of selection among different cosmetics formulations ${ }^{16}$. Additionally, the rheological characteristics can inter-

\section{Discussão}

Quando tratamos de desenvolvimento de produtos cosméticos, é de suma importância levarmos em consideração os ensaios diversos que devem ser realizados conforme preconiza a instância sanitária de competência nacional ${ }^{11}$.

A avaliação de parâmetros descritos como índice de fluxo e índice de consistência, correspondem as variáveis inerentes ao produto cosmético, cuja determinação é considerada essencial para configurar assim a estabilidade física de cosméticos ${ }^{12}$.

Em formulações dermocosméticas amplamente utilizadas como veículos de substâncias ativas, almeja-se o fluxo pseudoplástico, pois tais formulações têm sua viscosidade aparente diminuída gradualmente, à medida que aumenta a tensão de cisalhamento ${ }^{13}$, o que facilita a aplicação dos produtos na pele.

Sabe-se que no desenvolvimento de géis, é de extrema relevância o estudo das características reológicas, ao se considerar seus processos de fabricação, transporte, armazenamento e uso pelos consumidores. Neste aspecto, o estudo reológico considera várias propriedades das formulações cosméticas como textura, consistência, espalhabilidade. Essas características apresentam fatores importantes na determinação de escolhas de compra para os diversos tipos de usuários ${ }^{14}$.

Os valores médios referentes aos índices de fluxo das amostras analisadas em diferentes tempos e na temperatura ambiente, nos quais estão representados na Tabela 3 , nos indicaram que todas as formulações apresentaram comportamento pseudoplástico (onde $n<1$ ). Segundo a literatura científica para as formulações de uso tópico, o comportamento pseudoplástico é considerado apropriado, pois após o cisalhamento (aplicação de uma força de espalhabilidade) a resistência inicial para o produto fluir diminui, possibilitando assim uma melhor aplicação e espalhabilidade, e com a redução da intensidade desta força de cisalhamento a resistência ao fluxo volta a aumentar progressivamente ${ }^{15}$.

A análise das quatro formulações analisadas nos diferentes tempos e em temperatura ambiente, através dos reogramas apresentados na Figura 1 permite observar que todas as formulações apresentaram comportamento pseudoplásticos e tixotrópico, ou seja, ocorre uma diminuição da viscosidade, com o aumento da taxa de cisalhamento ao longo do tempo. Estas formulações com a aplicação de uma força tornar-se-ão mais fluidas, o que poderá facilitar a espalhabilidade do produto na pele quando forem aplicadas.

As características reológicas de cosméticos estão estreitamente relacionadas com seu enchimento e retirada do 
fere with final acceptance of the product, thus influencing the sensory effects caused by them.

The type of formulation and consumer acceptance in the face of the cosmetic product sensory characteristics can influence in a significant way in the final choice of product. Thus, the sensory evaluation is important for the success of a cosmetic tool, since one must consider that perceptions of product quality to a formulator and to a consumer are different. According to the results obtained in the study, we can see that the "smell" was the only sensory attribute affected by formulation type. The F3 and F4 formulations showed the highest odor acceptability between the formulations tested, indicating that the green clay associated with the presence of dimethicone had a positive influence on the acceptance of the formulation. The attributes of spreadability, stickiness, color and feel upon application were similar for all formulations tested, showing that these attributes were not affected by the concentration of green clay or dimethicone.

Parente et al. (2005) and Ares et al. (2008) studied the spreadability and stickiness of some pure emollients, including esters, silicone, and dimethicone, and observed that dimethicone differed from other emollients tested by demonstrating high values of 'hard scattering' and 'stickiness' which were not observed in this study . This can be attributed to the fact that the authors have studied the performance of unmixed (isolated) emollients in cosmetic preparations.

Sensory analysis studies are important for the development of cosmetics, and although there are still few studies that correlate rheological behavior on sensory acceptance, we believe that in the near future we can find ways to correlate them.

\section{Conclusion}

The presence of dimethicone in the formulation allowed greater acceptance for the attribute of smell.

Cosmetic dermatology is an area of constant innovation, and the emergence of new technologies and new raw materials. It is very important for dermatologists to be watchful and critical of the composition of new cosmetics so that the dermatological patient has a better adherence to treatment of acne. material de acondicionamento, com a espalhabilidade e a aderência destas sobre a pele. Assim, o estudo destas características (viscosidade, ponto de fluidez, espalhabilidade) pode ser utilizado como meio de seleção entre diferentes formulações cosméticas ${ }^{16}$. Além disso as características reológicas podem interferir na aceitação final do produto, podendo influenciar no efeito sensorial ocasionado pelos mesmos.

O tipo de formulação e a aceitação do consumidor frente às características sensoriais do produto cosmético podem influir de maneira importante na escolha final. Assim, a avaliação sensorial é um instrumento importante para o sucesso de um produto cosmético, uma vez que se deve considerar que as percepções de qualidade de um produto para um formulador e um consumidor são diferentes. De acordo com os resultados obtidos no estudo, podemos perceber que o 'odor' foi o único atributo sensorial afetado pelo tipo de formulação. As formulações F3 e F4 foram as que apresentaram maior aceitabilidade de odor entre as formulações testadas, indicando que a argila verde associado à presença de dimeticonte interferiu positivamente na aceitação da formulação. Já os atributos espalhabilidade, pegajosidade, cor e sensação após aplicação foram similares para todas as formulações testadas, mostrando que esses atributos não foram afetados pela concentração de argila verde ou dimeticone.

Parente et al. (2005) e Ares et al. (2008) estudaram a espalhabilidade e a pegajosidade de alguns emolientes puros incluindo ésters e silicone, e observaram que o dimeticone se diferenciava dos demais emolientes testados por apresentar altos valores para 'dificuldade de espalhamento' e 'pegajosidade', que não foram observados neste estudo. Isto pode ser atribuído ao fato dos autores terem estudado o desempenho dos emolientes isolados e não misturados em preparações cosméticas.

Estudos de análise sensorial são importantes para o desenvolvimento de cosméticos, e apesar de ainda existirem poucos estudos que correlacionam comportamento reológico com aceitação sensorial, acreditamos que num breve futuro poderemos encontrar maneiras de correlacioná-los.

\section{Conclusão}

A presença do dimeticone na formulação permitiu maior aceitação, para o atributo odor.

A dermatologia cosmética é uma área de constantes novidades, com frequente surgimento de novas tecnologias e novas matérias-primas. É de suma importância que o dermatologista esteja atento e crítico a composição destes novos cosméticos, para que assim o paciente dermatológico tenha uma melhor adesão ao tratamento da acne. 


\section{Conflict of Interest}

The authors declare that there is no financial or personal relationship that can be understood as representing a potential conflict of interest.

\section{Conflito de interesses}

Os autores declaram que não há nenhuma relação financeira ou pessoal, que possa ser entendida como representando um potencial conflito de interesses. 


\section{References / Referências}

1. Brito MFM, Galindo JCS, Santos JB, Sant'Anna IP, Rosendo LH PM. Avaliação dos efeitos adversos clínicos e alterações laboratoriais em pacientes com acne vulgar tratados com isotretinoína oral. An. Bras. Dermatol. 2010; 85(3): 331-337.

2. Bourgeois P. El Extraordinario poder curativo de La Argila. Barcelona: De Vicchi; 2006.84(3):93.

3. Costa A, Michalany NS, Alchome MMA, Lima HC. Acne vulgar: estudo piloto de avaliação do uso oral de ácidos graxos essenciais por meio de analises clinicas, digital e histopatológica. Anais Brasileiros de Dermatologia. 2007;82(2):129-134.

4. Zague V, Baby AR, Velasco MV R. Arcillas: Naturaleza en las máscaras faciales. Global Cosmetic Industry Latinoamérica. 2005; 4(3):36-39.

5. Chorilli M, Campos GR, Bolfarini PML Desenvolvimento e estudo da estabilidade físico-química da emulsões múltiplas $\mathrm{A} / \mathrm{O} / \mathrm{A}$ $\mathrm{E} \mathrm{O} / \mathrm{A} / \mathrm{O}$ acrescidas de filtros químicos e manteiga de Karité. Latin American Journal of Pharmacy,2009 ; 28(6):936-940.

6. Chandra RV, Malcolm J, Grimson1, Peter RW, Paul H, Bronwen GS. Rheological and structural properties of high-methoxyl esterified, low- methoxyl amidated pectin gels. Journal of Texture Studeis.2010:41;899-927
7. Almeida IF, Gaio AR, Bahia MF. Hedonic and descriptive skinfeel analysis of two oleogels:comparison with other topical formulations. Journal of Sensory Studies.2008:23;92-113.

8. Hurler J, Engesland A, Kermany BP, Basnet KN. Improved Texture Analysis for Hydrogel Characterization:Gel Cohesiveness, Adhesiveness, and Hardness. Journal of Applied Polymer Science.2012:125;180-188.

9. Lukic M, Jaksiv I, Krstonosic V, Cekic N, Savic S. A combined approach in characterization of an effective w/o hand cream: the influence of emollient on textural, sensorial and in vivo skin performance. International Journal of Cosmetic Science. 2012: 34; 140-149.

10. ANVISA. Agencia Nacional de Vigilância Sanitária. Guia de Controle de Qualidade de Produtos Cosméticos: Uma Abordagem Sobre os Ensaios Físicos e Químicos. Brasília: ANVISA, V.1, 52p. 2007.

11. Corrêa NM, Junior FBC, Ignacio RF, Leonardi GR. Avaliação do comportamento reológico de diferentes géis hidrofílicos. Revista Brasileira de Ciências Farmacêuticas. 2005; 41(1): 76-76.

12. Almeida I, Bahia MF. Reologia: Interesse e Aplicações na Área Cosmética-Farmacêutica. Cosmetics\&Toiletries(Brasil). 2003; 15(3):96-100.
13. Rebello TFS. O Operados e a Reologia. Cos metics\&Toiletries(Brasil).2005; 17:32.

14. Milan ALK. Estudo da Hidratação da Pele por Emulsões Cosméticas para Xerose e sua Estabilidade por Reologia. Revista Brasileira de Ciências Farmacêuticas.2007;43(4):650

15. Leonardi GR, Corrêa MN, Júnior FBC, Ignácio RF. Avaliação do comportamento reológico de diferentes géis hidrofílicos. Revista Brasileira de Ciencias Farmaceuticas.2005; 41(1)

16. Morais GG, Santos ODH, Masson DS, Oliveira WP, Filho PAR. Developmentof O/W emulsions with annato oil (Bixa orellana) containing liquid crystal. J. Dispers. Sci. Technol.2005;26(5): 591-596.

17. Parente ME, Gámbaro A, Ares G. Sensory Characterization of emollientes. Journal of Sensory Studies, 2008 ;23:149-161.

18. Ares G, Gambaro A. Influence of gender, age and motives underlying food choice on perceived healthiness and willingness to try functional foods. Appetite.2007:49(1): 148158. 